\title{
Вплив «західної» дієти на розвиток атеросклерозу
}

\author{
І.О. Мельничук, М.Л. Шараєва, В.Н. Крамарьова, В.Г. Лизогуб
}

Національний медичний університет імені О.О. Богомольця, Київ, Україна

\begin{abstract}
Анотація. Огляд та аналіз сучасних наукових даних щодо впливу тривалого дотримання так званої західної дієти та їі складових на розвиток атеросклерозу. Дієта $\epsilon$ провідною характеристикою способу життя. За даними багатьох досліджень, порушення здорової дієти $\epsilon$ важливим етіологічним фактором в патогенезі більшості хронічних захворювань, в тому числі атеросклерозу. Атеросклероз - хронічне запальне захворювання, що уражує стінки артерій та характеризується прогресуючим накопиченням ліпідів та запальних клітин під інтимою крупних артерій. На теперішній час приділяється багато уваги факторам кардіометаболічного ризику виникнення і прогресування атеросклерозу як поліетіологічного захворювання, особливо при нездоровому способі життя, в тому числі порушенні дієти. Сучасна «західна» дієта (ії також називають м'ясо-солодкою) $є$ однією з провідних в розвинених країнах та деяких країнах, що розвиваються. Патогенетично дія такої дієти пояснюється її впливом безпосередньо на стан мікробіому кишечнику та дисбалансом макро- та мікронутрієнтів. По-перше, тривале дотримання «західної» дієти призводить до розвитку дисбіозу кишечнику за рахунок підвищення вмісту грамнегативних мікроорганізмів, умовно-патогенної мікрофлори. Крім того, ця дієта характеризується надмірним вживанням насичених жирних кислот, холестерину, простих цукрів, рафінадів, $\omega-6$ жирних кислот, натрію, глютену та недостатнім вмістом деяких вітамінів та мікроелементів, а саме вітамінів A, D, B 12 та K ${ }_{2}$ магнію, хрому, поліненасичених жирних кислот та ін. Доведено, що зміна раціону харчування може знижувати ризик серцево-судинних подій приблизно на 80\%. Особливо важливим вважається для кожної людини в сучасних умовах дотримання принципів здорового харчування з метою профілактики атеросклерозу.
\end{abstract}

Ключові слова: «західна» дієта, атеросклероз, мікробіом кишечнику, холестерин, насичені жирні кислоти.

Дієта є провідною характеристикою способу життя. За даними багатьох досліджень, порушення здорової дієти $\epsilon$ важливим етіологічним фактором в патогенезі більшості хронічних захворювань, в тому числі атеросклерозу (АС) [1]. AC - хронічне запальне захворювання, що уражує стінки артерій та характеризується прогресуючим накопиченням ліпідів та запальних клітин під інтимою крупних артерій [2].

Вважається, що атерогенний процес супроводжується опосередкованими кровотоком запальними змінами ендотелію. Активація ендотеліальних клітин провокує синтез багатьох прозапальних біологічно активних факторів, що ініціює інфільтрацію моноцитами та лімфоцитами артеріальної стінки та запускає подальші прозапальні зміни. Високий рівень ліпопротеїдів низької щільності (ЛПНЩ) призводить до їх оксидації та накопичення під інтимою, супроводжується дисліпідемією, що веде до розвитку атеросклеротичної бляшки (АСБ). При цьому моноцити трансформуються в макрофаги і в подальшому накопичують ЛПНЩ в пінистих клітинах. На пізніх стадіях АС відбувається деградація колагенових волокон в екстрацелюлярному матриксі АСБ, що пов'язано з формуванням ускладненої вразливої бляшки. Розрив АСБ призводить до активації та агрегації тромбоцитів, активації каскаду коагуляції та формування тромбу. На цій стадії розвивається клінічна маніфестація АС — інфаркт міокарда, інсульт [1-3].

На даний час багато уваги приділяється факторам кардіометаболічного ризику виникнення і прогресування АС як поліетіологічного захворювання, таким як артеріальна гіпертензія, цукровий діабет, тютюнопаління, ожиріння, дисліпідемія та нездоровий спосіб життя. Дієта $\epsilon$ важливим компонентом способу життя. Згідно з діючими клінічними рекомендаціями [4] для корекції дисліпідемії пацієнтам рекомендується здорова дієта з низьким вмістом насичених жирів та переважанням цільнозернових продуктів, овочів, фруктів та риби. Історично склалося, що в кожній культурі існує свій спосіб харчування, деякі з них сприяють здоровому способу життя, інші - підвищують ризик розвитку АС. При цьому в усьому світі здорові дієти зазвичай мають спільні риси, незважаючи на різний склад макронутрієнтів. Вважається, що не тільки виключення з раціону насичених жирів, трансжирів та холестерину зумовлює зниження рівня ЛПНЩ, а й сприятливу дію чинить вживання деяких інших харчових компонентів (фітостероли, монаколін та червоний дріжджовий

рис, харчові волокна, соя, поліконазол та берберин, $\omega$-3 ненасичені жирні кислоти (ЖК)) [1, 4].

Популярність «західної» дієти в світі зростає щорічно, що зумовлено процесами глобалізації. Нині вона стала переважаючою в багатьох розвинених країнах та в деяких країнах, що розвиваються. «Західну» дієту почали відрізняти ще з середини минулого сторіччя, коли з'явилися нові методи переробки харчових продуктів, включаючи додавання зернових, рафінованого цукру та рафінованої рослинної олії, а також збільшився вміст жиру в м'ясі домашньої худоби та птиці. Нещодавно популярним стало замінювати цукор кукурудзяним сиропом з високим вмістом фруктози, що також $є$ характеристикою «західної» дієти сьогодення $[1,5]$.

«Західну» дієту ще називають «м'ясо-солодкою», бо вона характеризується надмірним вживанням червоного обробленого м'яса, упакованих продуктів, вершкового масла, цукерок та інших солодощів, смаженої їжі, продуктів тваринного походження, жирних молочних продуктів, яєць, рафінованих зерен, картоплі, кукурудзи (та кукурудзяного сиропу з високим вмістом фруктози), напоїв $з$ високим вмістом цукру водночас із низьким споживанням фруктів, овочів, цільного зерна, риби, горіхів та насіння. Антиподом «західної» дієти $\epsilon$ загальновідома «середземноморська» дієта, яка залишається досить поширеною в деяких європейських країнах та $\epsilon$ прикладом здорового харчування [4-6]. Крім того, популярності в останні роки набуває вивчення таких дієтичних режимів, як «скандинавська» та «DASH»-дієти, 5 різних овочів та фруктів протягом доби $[7,8]$.

Тривале дотримання «західної» дієти призводить до збільшення маси тіла, порушення ліпідного метаболізму та енергетичного обміну, активації імунної системи. Крім того, західний спосіб життя зазвичай асоціюється з іншими змінами, які також можуть бути причиною активації імунної системи та виявляти проатерогенний ефект при зниженні фізичної активності, збільшенні кількості стресів, зменшенні контактів з мікробними інфекціями, забрудненням повітря. «Західну» дієту вже давно розглядають як відомий етіологічний чинник розвитку абдомінального ожиріння, інсулінорезистентності, гіперглікемії, дисліпідемії, артеріальної гіпертензії та навіть старіння [9].

Патогенетично дія «західної» дієти пояснюється ії впливом безпосередньо на стан мікробіому кишечнику і дисбалансом макро- та мікронутрієнтів (рисунок). Тривале дотримання такої дієти призво- 
дить до розвитку дисбіозу кишечнику за рахунок підвищення вмісту грамнегативних мікроорганізмів. Стан мікробіому кишечнику при «західній» дієті характеризується зниженням вмісту Bacteroides та зростанням Firmicutes, Actinobacteria та Proteobacteria. Надмірне вживання насичених ЖК асоціюється зі зменшенням біфідо- та лактобактерій, а також появою патогенних для кишкового мікробіому дельтапротеобактерій (наприклад Bilophila wadsworthia) та ентеробактерій (наприклад Escherichia coli). «Західна» дієта безпосередньо та зміни мікробіому кишечнику, які вона провокує, призводить до підвищення рівня інтерстиціонального $\mathrm{pH}$, що також суттєво впливає на склад мікробіому кишечнику, потенціюючи ріст патогенної мікрофлори. Зміни складу кишкового мікробіому впливають на місцеву імунну відповідь, підвищуючи проникність кишкового бар'єра, а також викликаючи системну та слизову імунну відповідь. Дисбіоз кишечнику призводить до розвитку хронічної ендотоксинемії. Останнім часом навіть виділено групи захворювань, пов'язаних зі станом кишкового мікробіому, - функціональні захворювання шлунково-кишкового тракту, кишкові інфекції, запальні захворювання кишечнику, захворювання печінки, злоякісні пухлини шлунково-кишкового тракту, ожиріння та метаболічний синдром, цукровий діабет, алергічні захворювання, бронхіальна астма, аутизм та ін. $[10,11]$.

Рисунок Роль «західної» дієти в патогенезі АС

\section{Надлишок:}

Насичені ЖК, трансжири, холестерин, $\omega-6$ ЖК, прості цукри, рафінади, глютен, натрій, пурини, карнітин, гістидин

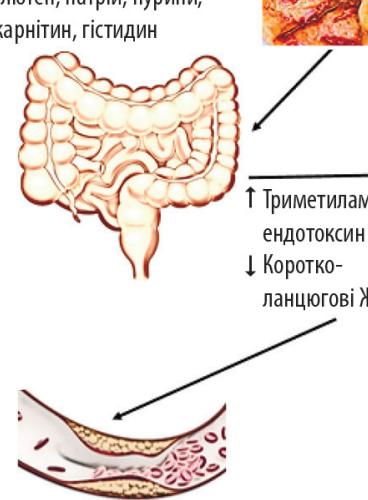

$\uparrow$ Холестерин, ліпопротеїди низької щільності ліпопротеїди дуже низької щільності, тригліцериди, сечова кислота,

триметиламін $\mathrm{N}-\mathrm{oксид}$

$\downarrow$ оксид азоту

Виявлено, що «західна» дієта характеризується дисбалансом нутрієнтів та дієтичних метаболітів (табл. 1), а саме надмірним вживанням насичених ЖК, транс-ЖК, холестерину, простих цукрів, рафінадів, $\omega-6$ ЖК, натрію, глютену $[9,12]$.

Таблиця 1 Нутрієнти тадієтичні метаболіти, характерні для «західної» дієти

\begin{tabular}{lcc}
\hline \multicolumn{1}{c}{ Нутрієнт } & $\begin{array}{c}\text { Ефект щодо формування } \\
\text { метаболічного синдрому }\end{array}$ & $\begin{array}{c}\text { Про-/протизапальний } \\
\text { ефект }\end{array}$ \\
\hline Насичені ЖК, транс-ЖК & Потенціює & Прозапальний \\
\hline Холестерин & Потенціює & Прозапальний \\
\hline Прості цукри, рафінади & Потенціює & Прозапальний \\
\hline$\omega-6$ ЖК & Потенціює & Прозапальний \\
\hline Глютен & Потенціює & Прозапальний \\
\hline Пурини & Потенціює & Прозапальний \\
\hline Карнітин & Потенціює & Прозапальний \\
\hline Гістидин & Невідомо & Прозапальний \\
\hline
\end{tabular}

\section{Насичені ЖК, транс-ЖК}

Насичені ЖК - одні із провідних макронутрієнтів в загальному раціоні людини, сприяють абсорбції та розчиняють жиророзчинні вітаміни та інші мікронутрієнти. Вони використовуються для деяких провідних функцій в організмі, $\epsilon$ важливим джерелом енергії, будівельним елементом фосфоліпідної мембрани, забезпечують модифікацію білків та регулюють транскрипцію генів. Але на даний час в розвинених країнах насичені ЖК забезпечують $>1 / 3$ енергетичної потреби організму, тоді як раніше - лише 5-7\%. Доведено, що надмірне вживання насичених ЖК викликає зростання рівня ЛПНЩ та тригліцеридів (ТГ) у крові. Так, виявлено, що надмірне вживання насичених ЖК стимулює ліпонеогенез і розвиток інсулінорезистентності, а в подальшому - неалкогольної жирової хвороби печінки (НАЖХП). Насичені ЖК призводять до збільшення вмісту грамнегативної флори в кишечнику, що активує продукцію ліпополісахариду (ендотоксину) і покращує його всмоктування, який, зв'язуючись 3 toll-подібними рецепторами-2 та -4 жирової тканини при активації макрофагів викликає формування перманентного запалення [13].

Вживання трансжирів асоціюється з розвитком АC, дисліпідемії, цукрового діабету, онкологічних захворювань. Вони впливають безпосередньо на стан мікробіому кишечнику, підвищуючи проникність кишкового бар'єру. При всмоктуванні вони інгібують секрецію аполіпопротеїду В-100 в гепатоцитах, що порушує катаболізм ЛПНЩ. Також транс-ЖК активують моноцити та макрофаги, збільшують продукцію ними прозапальних інтерлейкіну (ІЛ)-6 та фактора некрозу пухлини а (tumor necrosis factor a - TNF-a). TрансЖК, імовірно, відіграють роль у формуванні ендотеліальної дисфункції та здатні порушувати продукцію NO [14].

\section{Холестерин}

Холестерин, який вживає людина, 3 хіломікронами та ТГ через портальний кровотік потрапляє до гепатоцитів, де за допомогою ліпопротеїнліпаз більша його кількість розщеплюється на ЖК. Однак деяка його частка безпосередньо входить до ліпопротеїдів дуже низької щільності, які секретуються гепатоцитами. Також значна частка ЖК, що вивільняється і не застосовується для будування мембран клітин, використовується для побудови ЛПНЩ, які $\epsilon$ джерелом холестерину для будь-якої клітини тіла. Якщо в клітинах виникає дефіцит і не вистачає холестерину, то він відкладається в ліпопротеїдах високої щільності (ЛПВЩ). Інша частина ЖК в гепатоциті використовується для синтезу жовчних кислот та стероїдів, а надмірні їх залишки $\epsilon$ причиною розвитку оксидативного стресу, накопичення ЖК в гепатоциті та через активацію інфламасом викликає надмірний синтез ІЛ-1 $\beta$ [15]. Крім того, надмірне вживання холестерину з їжею безпосередньо змінює стан кишкової мікробіоти ії склад, активність та проникність кишкового бар'єру [16].

\section{Прості цукри, рафінади}

Відомою $\epsilon$ роль надмірного вживання простих цукрів та рафінадів в патогенезі метаболічних захворювань: ожиріння, НАЖХП, АС та дисліпідемії. Останнім часом виявлено прозапальні властивості надмірного вживання простих цукрів (глюкози та фруктози), особливо в напоях. Патогенетично це пов'язано з впливом на стан мікробіому кишечнику та проникність кишкової стінки [17-19].

Рафіновані зерна, аналогічно до простих цукрів, також патогенетично чинять свою дію через зміну стану мікробіому кишечнику. Крім того, рафіновані зерна втрачають зі свого складу деякі життєво важливі мікронутрієнти. Вживання рафінованих зерен достовірно пов'язане зі зростанням вмісту С-реактивного білка (СРБ) та TNF-a у плазмі крові. Рафіновані зерна здатні викликати виражену постпрандіальну гіперглікемію, зростання вмісту інсуліну та гіпертригліцеридемію [20, 21]. Таким чином, вживання рафінованих продуктів асоціюється з підвищеним ризиком серцево-судинних захворювань, в тому числі АС, ожиріння, цукрового діабету 2-го типу, онкологічних захворювань та загальної смертності [22].

\section{w-6}

«Західна» дієта надмірно багата на $\omega-6$ ЖК (лінолеву, арахідонову, ейкозадиєнову та докозадієнову кислоти). За таких умов їх співвідношення до $\omega$-3 ЖК в щоденному раціоні становить до 17/1, в той час коли оптимальним $\epsilon$ співвідношення 4/1, а, за деякими даними, навіть 2-2,5/1. Враховуючи, що $\omega-6$ ЖК $\in$ антагоніс- 
тами $\omega-3$ ЖК, вони інгібують їх протизапальну дію. Відомим $\epsilon$ факт, що $\omega$-6 ЖК відіграють незаперечну роль в патогенезі процесів запалення: з їх надмірним вживанням пов'язують зростання захворюваності на серцево-судинну, онкологічну патологію, запальні та аутоімунні хвороби [23, 24]. Так, арахідонова кислота, одна з важливих $\omega-6$ ЖК, $\epsilon$ провідним прекурсором багатьох прозапальних ейкозаноїдів: простагландинів $\left(E_{2}\right.$ та $\left.F_{2 a}\right)$, тромбоксанів $\left(A_{2}\right)$, лейкотрієнів $\left(\mathrm{B}_{4^{\prime}} \mathrm{C}_{4^{\prime}} \mathrm{D}_{4^{\prime}} \mathrm{E}_{4}\right)$, резорвінів, ліпоксинів та прооксидантів, які, в свою чергу, потенціюють синтез генів рецепторів SREBP-1c та фактора некрозу kB (NF-kB) і знижують PPARa. Таким чином, переважання в клітинній стінці $\omega-6$ ЖК призводить до розвитку перманентного запального процесу в тканині, вони активують оксидативний стрес, ендотеліальну дисфункцію та синтез ЛПНЩ [25].

\section{Глютен}

Глютен - складна суміш сотень споріднених, але різних білків, переважно гліадину та глютеніну. Пшеничні ядра містять 8-15\% білка, з яких 10-15\% - альбумін/глобулін, а 85-90\% — глютен. Загалом білки гліадину та глютеніну відносять до проламінів, які являють собою білки, нерозчинні у воді, але спирторозчинні, що характеризуються високим рівнем глутаміну (38\%) та залишків проліну (20\%). Саме через високий вміст проліну та глутаміну, які не здатні розщеплюватися протеазами, глютен $\epsilon$ високостійким до шлункового, підшлункового та кишкового протеолітичного травлення в шлунково-кишковому тракті, а також нездатний до перетравлювання в кишечнику людини. Залишки проліну здатні утворювати щільні та компактні структури та активувати Т-клітини через зростання синтезу ІЛ-1 $\beta$ та -18 $[26,27]$. Глутамін має проалергічні властивості, а також здатен активувати цитотоксичні Т-клітини та фібробласти. Рівень тканинних трансглутаміназ та їх активність прямо пов'язані з рівнем глутаміну, бо впливають на проникність кишкового ендотелію, а отже, і на рівень кишкових метаболітів у крові [26-28].

\section{Пурини}

Відомо, що «західна» дієта багата на пурини, до яких належать інозинмонофосфат, аденозинмонофосфат та, безпосередньо, сечова кислота (СК). Крім того, виявлено, що синтез СК з РНК, ДНК та ендогенного аденозинтрифосфату (АТФ) значно посилюється при дієті з високим глікемічним індексом та високим вмістом солі. Також СК здатна синтезуватися з амінокислотпопередників: гліцину, глутаміну та аспартату. Синтез СК може відбуватися у тканині печінки та тонкому кишечнику, а екскреція СК - через нирки, кишечник та шкіру (з потом). Тому стан мікробіому кишечнику відіграє важливу роль у процесах синтезу, всмоктування та виділення СК [29].

За статистичними даними, у кожної 4-ї дорослої людини відмічають гіперурикемію. Гіперурикемія - відомий компонент метаболічного синдрому та фактор ризику розвитку АС. Цікавим $\epsilon$ факт, що наявність АС, в свою чергу, потенціює гіперурикемію. Надмірний вміст СК призводить до розвитку оксидативного стресу та синтезу прозапальних цитокінів, інфламасом, білків теплового шоку та активації NF-kB, а також ендотеліальної дисфункції та вазоконстрикції [29, 30].

\section{Карнітин}

Надмірне споживання червоного м'яса тваринного походження, що $\epsilon$ характерним для «західної» дієти, $\epsilon$ доведеним фактором ризику розвитку серцево-судинних подій. Вважається, що це пов'язано з підвищеним вмістом в червоному м'ясі насичених жирів та холестерину, а також з надмірним споживанням солі та гетероциклічних вуглеводнів, які використовуються при його приготуванні. Червоне м'ясо багате на карнітин, який $\epsilon$ попередником триметиламіну (ТМА) та триметиламін-N-оксиду (TMAO), що мають доведений проатерогенний ефект. Також, за останніми даними, L-карнітин здатен безпосередньо потенціювати процеси AC. При дотриманні «західної» дієти L-карнітин та холін, що містяться переважно в червоному м'ясі та жирних молочних продуктах, можуть становити близько $2 \%$ всього денного раціону [31]. L-карнітин не здатен розщеплюватися в організмі еукаріотів - людському організмі, тому така дієта безпосередньо впливає на склад кишкового мікробіому хазяїна. Надмірне вживання L-карнітину підвищує його безпосередній вміст в плазмі крові че-

рез підвищення проникності кишкового бар'єру та нездатність мікробіому кишечнику переробити його на ТМА в такій кількості та підвищує вміст його метаболітів ТМА та ТМАО. У свою чергу, ТМА та ТМАО здатні підвищувати абсорбцію холестерину в кишечнику, порушувати метаболізм холестерину в печінці (інгібувати продукцію 3 нього стероїдів, що $є$ попередниками жиророзчинних гормонів) та забезпечувати прозапальні зміни в судинній стінці (підвищувати міграцію макрофагів) [32].

ТМАО здатен порушувати синтез ЖК в печінці, виступаючи антагоністом фарнезоїдних X-рецепторів та рецепторів вітаміну D, що синтезуються в жовчі, печінці та сироватці крові, змінює їх профіль. Різні ЖК здатні по-різному впливати на обмін холестерину та ЛПнщ, а також на стан кишкової мікробіоти [33]. Також ТМАО здатен стимулювати продукцію прозапальних цитокінів, таких як ІЛ- $1 \beta$ та TNF-a, та знижувати продукцію протизапального ІЛ-10. Водночас ТМАО має протромботичні властивості шляхом активації тромбоцитів [34]. Зростання рівня ТМАО у плазмі крові призводить до мобілізації внутрішньоклітинного $\mathrm{Ca}^{2+}$, що викликає агрегацію тромбоцитів. Високий рівень циркулюючого ТМАО також посилює адгезію тромбоцитів до імобілізованого колагену в цільній крові, що суттєво сприяє реагуванню тромбоцитів на кілька інших агоністів та індукує каскадну реакцію утворення тромбу. Підвищення рівня ТМАО стійко асоціюється з ендотеліальною дисфункцією та зниженням синтезу NO. Biн бере участь у формуванні мікросудин у коронарних бляшках, що призводить до дисбалансу між антиангіогенними та проангіогенними факторами. Мікросудини залишаються незрілими, що робить їх більш вразливими до розриву і $\epsilon$ можливою причиною формування нестабільності АСБ. Водночас ТМАО здатен інгібувати зворотний транспорт холестерину (клітинний холестерин передається з периферичних тканин в печінку і кишечник для виведення 3 калом), що призводить до розвитку дисліпідемії [35].

\section{Гістидин}

Гістидин $є$ попередником гістаміну, який має прозапальні властивості, що може бути важливим в патогенезі АС. Виявлено, що гістидин здатен інгібувати NF-кB-активацію і стимулювати продукцію TNF-a, а також прозапального IЛ-6. Однак на сьогодні не існує однозначних даних щодо ролі гістидину в патогенезі АC [36, 37].

Водночас «західна» дієта характеризується недостатнім вмістом деяких вітамінів та мікроелементів (табл. 2), а саме вітамінів A, D, B 12 та K ${ }_{2}$ магнію, хрому, поліненасичених ЖК та ін. [38-42].

Таблиця 2 Нутрієнти, вітаміни та мікроелементи, вміст яких $\epsilon$ недостатнім в «західній» дієті

\begin{tabular}{|c|c|c|}
\hline Нутрієнт & $\begin{array}{l}\text { Ефект щооо формування } \\
\text { метаболічного синдрому }\end{array}$ & $\begin{array}{c}\text { Про-/протизапальний } \\
\text { ефект }\end{array}$ \\
\hline Харчові волокна & Протидія & Протизапальний \\
\hline Вітамін A & Протидія & Протизапальний \\
\hline Вітамін D & Протидія & Протизапальний \\
\hline Вітамін $K_{2}$ & Невідомо & Протизапальний \\
\hline Магній & Протидія & Протизапальний \\
\hline w-3 поліненасиченіЖК & Протидія & Протизапальний \\
\hline Поліфеноли & Протидія & Протизапальний \\
\hline Целастрол & Протидія & Невідомо \\
\hline
\end{tabular}

\section{Харчові волокна}

Харчові волокна - комплекс вуглеводів та лігніну, що не гідролізується ферментами людського організму i тому не абсорбується та не перетравлюється в людському організмі [43]. Їх фізико-хімічні характеристики включають бродіння, розчинність та в'язкість, що зумовлює їх терапевтичні ефекти. Харчові волокна здатні покращувати ліпідний спектр (знижувати рівень загального холестерину та лПнЩ в організмі), зменшувати вираженість гіперглікемії та інсулінорезистентності, виявляти протизапальний ефект, нормалізувати рівень артеріального тиску, маси тіла, мінерального обміну в кістках. Склад харчових волокон забезпечує стан мікробіому кишечнику: його склад, продукцію коротколанцюгових ЖК (особливо пропіонової кислоти) та бактеріальне бродіння, а також час пасажу калових мас по кишечнику, їх об'єм та евакуацію [44]. 


\section{Вітамін A}

Вітамін А - необхідний нутрієнт, що забезпечує багато важливих функцій організму людини, таких як зір, розмноження та лактація, ріст та розвиток, імунна відповідь. Широковідомими є протизапальний та антиоксидантний ефекти вітаміну А [45]. Виявлено, що прийом вітаміну А здатен нормалізувати рівень ЛПнЩ, а разом з вітаміном D - інгібувати IЛ-1 та -6, забезпечуючи антиатеросклеротичний ефект [46].

\section{Магній}

Магній в організмі людини $\epsilon$ важливим мікроелементом, що використовується як кофактор >300 ферментативних реакцій, забезпечуючи біохімічне функціонування багатьох метаболічних шляхів. Магній - 4-й за поширеністю мінерал в організмі людини після кальцію, натрію та калію і 2-й за частотою внутрішньоклітинний катіон після калію. В організмі людини в середньому міститься близько 25 г магнію. За даними деяких авторів, зниження сироваткового рівня магнію <85 ммоль/л можна вважати дефіцитом [1, 39, 42, 47, 48].

Магній бере участь у ферментативних реакціях, що забезпечують синтез білків, м'язову скоротливість, нервову функцію, контроль рівня глюкози у крові, активацію рецепторів гормонів, регуляцію артеріального тиску, серцеву збудливість, трансмембранний іонний потік, функціонування кальцієвих каналів, а також синтез РНК та ДНК. Він використовується для енергопродукції — в процесах метаболізму АТФ, оксидативного фосфорилювання, гліколізу. Крім того, магній має протизапальні властивості - знижує синтез NF-kB, TNF-a та цитокінову експресію, а через них знижує активність макрофагів, Т-хелперів та натуральних кілерів. В експерименті на тваринах доведена здатність додавання магнію в їжу зменшувати прояви АС. Дія нормальних рівнів магнію на АСБ порівнянна з дією статинів, однак магній можна швидше назвати контролером ферменту 3-гідроксил-3метилглутарил-коферменту А-редуктази (ГМГ-СоА-редуктази), ніж його інгібітором. Магній також необхідний для активності лецитин-холестерин-ацилтрансферази (LCAT), яка знижує рівень ЛПНЩ і ТГ та підвищує рівень ЛПВЩ [1, 39, 42, 47-49].

Виявлено, що додавання магнію в раціон позитивно впливає на артеріальну жорсткість та стабілізує АСБ $[50,51]$. Сьогодні пропонуються стратегії корекції ендотеліальної дисфункції за допомогою прийому препаратів магнію [6]. Також магній $\epsilon$ природним антагоністом кальцію, а надмірне вживання кальцію призводить до зростання ризику серцево-судинних подій та загальної смертності [52]. Крім того, як антагоніст кальцію магній збільшує продукцію оксиду азоту, покращує дисфункцію ендотелію та індукує пряме та непряме розширення судин. У пацієнтів із найбільшим квартилем споживання магнію відмічали зниження раптової серцевої смерті на 77\%. Також відомо, що нестача вітаміну D призводить до порушення абсорбції магнію [42].

\section{Вітамін D}

Майже в 1 млрд людей в усьому світі відмічають дефіцит вітаміну D, це вважається найпоширенішим дефіцитом харчування. 3 1930-х років вітамін D відомий своєю роллю у всмоктуванні кальцію в кишечнику та мінералізації кісток. Однак спостереження за сезонними змінами артеріального тиску та подальша ідентифікація рецептора вітаміну D (VDR) та 1a-гідроксилази в кардіоміоцитах, а також клітинах гладких м'язів ендотелію та судин, змінили погляд на його роль в патогенезі кардіологічних захворювань. Вважається, що сигнальний шлях вітаміну D важливий для серцево-судинної цілісності, особливо для регуляції судинного тонусу, а також як антифібротичний та антигіпертрофічний сигнальний шлях у серцевому м'язі $[53,54]$. За деякими даними, зниження рівня 25-гідроксивітаміну D у плазмі крові $\epsilon$ предиктором розвитку метаболічних порушень, а саме вісцерального ожиріння $[55,56]$. Про роль вітаміну D в патогенезі запалення свідчить зворотна кореляція між рівнем 25-гідроксивітаміну D у плазмі крові з матриксною металопротеїназою-9, роль якої в механізмі розвитку АС та серцевого ремоделювання $\epsilon$ відомою [57].

Попередник вітаміну D, 7-дегідрохолестерол, $\epsilon$ також попередником синтезу холестерину. Проведено багато досліджень та метааналізів щодо ролі вітаміну $\mathrm{D}$ в ліпідному метаболізмі та доцільності призначення препаратів вітаміну $D$ для його корекції, однак однозначної думки не існує $[39,58]$. За деякими даними, хронічний дефіцит вітаміну D можна розглядати як один із нових факторів ризику AC [59]. Вітамін D чинить гормоноподібний вплив на фактори росту, міграції та диференціації клітин, модулює імунну відповідь під час запалення та фіброзу та відіграє вирішальну роль в усіх ланках атерогенезу — від розвитку ендотеліальної дисфункції до тромбозу. Крім того, виявлено, що VDR знаходяться у міокардіоцитах, клітинах ендотелію, гладком'язових клітинах судин та деяких імунних клітинах. Зв'язуючись 3 VDR, вітамін D активує транскрипцію ДНК в клітині та, за деякими даними, активує продукцію NO. Тому саме недостатня активація VDR може детермінувати прозапальний ендотеліальний NF-кB сигнальний шлях зі зростанням лейкоцитарно-ендотеліальної клітинної взаємодії, що здатне сприяти атерогенезу. Отже, вітамін D впливає на процеси запалення при AC за допомогою різних механізмів, таких як інгібування шляху простагландин/циклооксигеназа, підвищення регуляції протизапальних цитокінів, зменшення молекул адгезії, зниження активації металопротеїнази-9 і регулювання системи ренін — ангіотензин [59]. Субклінічний АС, підвищення жорсткості судинної стінки тісно асоціюються з хронічним дефіцитом вітаміну D, хоча призначення препаратів вітаміну $D$ не продемонструвало сприятливих результатів у хворих з коронарним AC $[60,61]$. Виявлено, що вітаміни D та К виявляють синергічний ефект на процеси кальцифікації АСБ $[62,63]$.

\section{Вітамін K}

Вітамін К - жиророзчинний вітамін, який $є$ важливим мікронутрієнтом. Вітамін К складається з вітаміну $\mathrm{K}_{1}$ (фітонадіону), що міститься переважно в темно-зелених листових овочах та насінні, та вітаміну $\mathrm{K}_{2}$ (менакінону-7), що переважно продукується кишковою мікрофлорою. Вітамін $\mathrm{K}_{2}$ становить 5-25\% загального вмісту вітаміну К в організмі людини. Також розрізняють вітамін $\mathrm{K}_{3}$ (менадіон) - синтетичний вітамін К. Рівень серцево-судинної смертності та процеси кальцифікації АСБ обернено пропорційно залежать від вмісту саме вітаміну $\mathrm{K}_{2}[38,63]$.

По-перше, вітамін $\mathrm{K}_{2}$ бере участь у синтезі матриксного Glaбілка (Matrix Gla protein - MGP) — тканинного інгібітора кальцифікації. Підвищення рівня неактивного MGP прямо асоціюється зі зростанням швидкості пульсової хвилі - показником судинної жорсткості та раннім маркером АС. Також до вітамін К-залежних білків належать фактори згортання крові (фактори II, VII, IX, X), циркулюючі антикоагулянти (білки C, S та Z) та білки, що беруть участь у мінералізації кісток та м'яких тканин (остеокальцин). По-друге, вітамін К чинить протизапальну дію - інгібує NF-кB-сигнальний шлях, а також проліферацію та активність Т-лімфоцитів, знижує експресію генів цитокінів, що пригнічує синтез IЛ-6. NF-кB-сигнальний шлях відіграє ключову роль в остеогенній диференціації не тільки мезенхімальних стовбурових клітин, але і гладком'язових клітин судинної стінки. Саме додавання вітаміну К зумовлює інгібування дії високих рівнів ліпополісахариду у плазмі крові через інгібування NF-кB-сигнального шляху. По-третє, виявлена роль вітаміну $\mathrm{K}_{2}$ в метаболізмі ліпідів, його нестача асоціюється зі зростанням рівня ЛПНЩ у плазмі крові. По-четверте, існують дані щодо здатності вітаміну $\mathrm{K}_{2}$ підвищувати синтез NO та зменшувати вираженість ендотеліальної дисфункції. Відомим $\epsilon$ зв'язок недостатності вітаміну $\mathrm{K}_{2}$ 3 жорсткістю артеріальної стінки. Цікавим $€$ факт, що саме рівень вітаміну $\mathrm{K}_{2}$, а не $\mathrm{K}_{1}$, зворотно асоціюється з розвитком проявів $\mathrm{AC}$, що може пояснити нездатність під час призначення вітаміну $\mathrm{K}_{1}$ отримати суттєвий антиатеросклеротичний ефект [38]. Існує багато робіт щодо здатності призначених препаратів вітаміну К зменшувати розвиток AC, однак однозначних результатів досі не отримано [62, 63]. Вивчаються антисклеротичні ефекти одночасного призначення вітамінів $\mathrm{K}_{2}$ та $\mathrm{D}_{3}$. Недостатність вітаміну $\mathrm{K}$ може бути зумовлена вживанням високих доз вітамінів А та Е внаслідок конкурентних механізмів, що $€$ характерним для «західної» дієти [64-66].

\section{$\boldsymbol{\omega}$-3 поліненасичені жк}

Останнім часом широко обговорюється роль $\omega$-3 поліненасичених ЖК в патогенезі АС, бо $\epsilon$ доведеною важливість дієти, багатої на них, з переважанням морської риби в профілактиці розвитку ліпідних порушень. $\omega$-3 поліненасичені ЖК чинять антиатеросклеротичну дію через протизапальні властивості (через 
активацію резольвіну $\mathrm{E}_{1}$ ), знижують відкладення коронарного кальцію (інгібують остеобластичну диференціацію та кальцифікацію судин), протидіють розвитку гіперплазії інтими через інгібування лейкоцитарних рецепторів та ендотеліальної дисфункції, чинять опір гіпертригліцеридемії. Але попри вищезазначене, суттєвого антиатеросклеротичного ефекту вживання $\omega$-3 поліненасичених ЖК, за даними літератури, не отримано [67-69].

\section{Висновки}

Таким чином, «західна» дієта та їі складові всебічно та суперечливо впливають на організм людини. Вона стимулює перманентне латентне запалення за рахунок хронічної ендотоксинемії, а також через підвищення синтезу прозапальних ейкозаноїдів (простагландинів $\mathrm{E}_{2}$ та $\mathrm{F}_{2 \mathrm{a}^{\prime}}$ тромбоксану $\mathrm{A}_{2^{\prime}}$ лейкотрієнів $\mathrm{B}_{4^{\prime}} \mathrm{C}_{4^{\prime}} \mathrm{D}_{4^{\prime}} \mathrm{E}_{4^{\prime}}$ резорвінів, ліпоксинів та прооксидантів), ІЛ-1 $\beta$, $-6,-18$, NF-kB, TNF-a та ін. Також надмірне вживання жирного червоного м'яса та яєчного жовтка асоціюється зі зростанням ТМА та TMAO, що $є$ причиною розвитку АС та дисліпідемії.

Виявлено, що зміна способу життя, а особливо раціону харчування, може знижувати ризик розвитку серцево-судинних подій приблизно на 80\% [70]. Детально клінічні рекомендації щодо здорового раціону харчування та способу життя неодноразово викладені в зарубіжних та вітчизняних джерелах [4].

Особливо важливим вважається для кожної людини в сучасних умовах дотримання принципів здорового харчування 3 метою первинної, вторинної та третинної профілактики АC, адже «західну» дієту можна сміливо назвати одним із провідних етіологічних чинників його розвитку.

\section{Конфлікт інтересів}

Конфлікт інтересів відсутній.

\section{Список використаної літератури}

1. Torres N., Guevara-Cruz M., Velázquez-Villegas L., Tovar, A. (2015) Nutrition and Atherosclerosis. Arch. Med. Res., 46(5): 408-426. doi: 10.1016/j.arcmed.2015.05.010

2. Falk E. (2006) Pathogenesis of Atherosclerosis. J. Am. Coll. Cardiol., 47(8): (7-C12. doi: 10.1016/j.jacc.2005.09.068.

3. Zhu Y., Xian X., Wang Z. et al. (2018). Research Progress on the Relationship between Atherosclerosis and Inflammation. Biomolecules, 8(3): 80. doi: 10.3390/biom8030080.

4. Mach, F., Baigent, C., Catapano, A. et al. (2019). 2019 ESC/EAS Guidelines for the management of dyslipidaemias: lipid modification to reduce cardiovascular risk. Eur. Heart J., 41(1): 111188. doi: 10.1093/eurhearti/ehz455.

5. Nazni P. (2014) Association of western diet \& lifestyle with decreased fertility. Indian J. Med. Res., 140(Suppl. 1): S78-S81.

6. Murphy C., Byrne J., Keogh J. et al. (2021) The Acute Effect of Magnesium Supplementation on Endothelial Function: A Randomized Cross-Over Pilot Study. Int. J. Envir. Res. Public Health, 18(10): 5303. doi: 10.3390/ijerph18105303.

7. Filippou C., Tsioufis C., Thomopoulos C. et al. (2020) Dietary Approaches to Stop Hypertension (DASH) Diet and Blood Pressure Reduction in Adults with and without Hypertension: A Systematic Review and Meta-Analysis of Randomized Controlled Trials. Adv. Nutrition, 11(5): 1150-1160. doi: 10.1093/advances/nmaa041.

8. Galbete C., Kröger J., Jannasch F. et al. (2018) Nordic diet, Mediterranean diet, and the risk of chronic diseases: the EPIC-Potsdam study. BMC Med., 16(1). doi: 10.1186/s12916-018$1082-y$.

9. Christ A., Lauterbach M., Latz E. (2019) Western Diet and the Immune System: An Inflammatory Connection. Immunity, 51(5): 794-811. doi: 10.1016/j.immuni.2019.09.020.

10. Bibbò S., laniro G. Giorgio V. et al. (2016) The role of diet on gut microbiota composition. Eur. Rev. Med. Pharmacol. Sci., 20(22): 4742-4749.

11. Myles I. (2014) Fast food fever: reviewing the impacts of the Western diet on immunity. Nutrition J., 13(61). doi: 10.1186/1475-2891-13-61.

12. Shively C., Appt S., Vitolins M. et al. (2019) Mediterranean versus Western Diet Effects on Caloric Intake, Obesity, Metabolism, and Hepatosteatosis in Nonhuman Primates. Obesity, 27(5): 777-784. doi: 10.1002/oby.22436.

13. Ruiz-Núñez B., Dijck-Brouwer D., Muskiet F. (2016) The relation of saturated fatty acids with low-grade inflammation and cardiovascular disease. J. Nutr. Biochem., 36: 1-20. doi: 10.1016/j.jnutbio.2015.12.007.

14. Islam M., Amin M., Siddiqui S. et al. (2019) Trans fatty acids and lipid profile: A serious risk factor to cardiovascular disease, cancer and diabetes. Diabetes \& Metabolic Syndrome: Clinical Research \& Reviews, 13(2): 1643-1647. doi: 10.1016/j.dsx.2019.03.033.
15. Püschel G., Henkel J. (2018) Dietary cholesterol does not break your heart but kills your liver. Porto Biomedical J., 3(1): e12. doi: 10.1016/j.pbj.0000000000000012.

16. Chaplin A., Carpéné C., Mercader J. (2018) Resveratrol, Metabolic Syndrome, and Gut Microbiota. Nutrients, 10(11): 1651. doi: 10.3390/nu10111651.

17. Farrell G., Schattenberg J., Leclercq I. et al. (2019) Mouse Models of Nonalcoholic Steatohepatitis: Toward Optimization of Their Relevance to Human Nonalcoholic Steatohepatitis. Hepatology, 69(5): 2241-2257. doi: 10.1002/hep.30333.

18. Khan S., Waliullah S., Godfrey V. et al. (2020) Dietary simple sugars alter microbial ecology in the gut and promote colitis in mice. Sci. Transl. Med., 12(567): eaay6218. doi: 10.1126/scitransImed.aay6218.

19. Martinez K., Leone V., Chang, E. (2017) Western diets, gut dysbiosis, and metabolic diseases: Are they linked? Gut Microbes, 8(2): 130-142. doi: 10.1080/19490976.2016.1270811.

20. Kim Y., Keogh J., Clifton P. (2016) Differential Effects of Red Meat/Refined Grain Diet and Dairy/ Chicken/Nuts/Whole Grain Diet on Glucose, Insulin and Triglyceride in a Randomized Crossover Study. Nutrients, 8(11): 687. doi: 10.3390/nu8110687.

21. Vanegas S., Meydani M., Barnett J. et al. (2017) Substituting whole grains for refined grains in a 6-wk randomized trial has a modest effect on gut microbiota and immune and inflammatory markers of healthy adults. Am. J. Clin. Nutr., 105(3): 635-650. doi: 10.3945/ ajcn.116.146928.

22. Gaesser G. (2019) Perspective: Refined Grains and Health: Genuine Risk, or Guilt by Association? Advances In Nutrition, 10(3): 361-371. doi: 10.1093/advances/nmy104.

23. Innes J., Calder P. (2018) Omega-6 fatty acids and inflammation. Prostaglandins, Leukotrienes And Essential Fatty Acids, 132: 41-48. doi: 10.1016/j.plefa.2018.03.004.

24. Simopoulos A. (2002) The importance of the ratio of omega- $6 /$ omega-3 essential fatty acids. Biomedicine \& Pharmacotherapy, 56(8): 365-379. doi: 10.1016/50753-3322(02)00253-6.

25. Patterson E., Wall R., Fitzgerald G. et al. (2012) Health Implications of High Dietary Omega-6 Polyunsaturated Fatty Acids. J. Nutr. Metabol., 2012: 1-16. doi: 10.1155/2012/539426.

26. Biesiekierski J. (2017) What is gluten? J. Gastroenterol. Hepatol., 32: 78-81. doi: 10.1111/ jgh.13703.

27. Kumar J., Kumar M., Pandey R., Chauhan N. (2017) Physiopathology and Management of Gluten-Induced Celiac Disease. J. Food Sci., 82(2): 270-277. doi: 10.1111/1750-3841.13612.

28. Lexhaller L. (2019) Comprehensive Detection of Isopeptides between Human Tissue Transglutaminase and Gluten Peptides. Nutrients, 11(10): 2263. doi: 10.3390/nu11102263.

29. Sanchez-Lozada L., Rodriguez-Iturbe B., Kelley E. et al. (2020) Uric Acid and Hypertension: An Update With Recommendations. Am. J. Hypertens., 33(7): 583-594. doi: 10.1093/ajh/ hpaa044.

30. Bove M., Cicero A., Veronesi M., Borghi C. (2017) An evidence-based review on urate-lowering treatments: implications for optimal treatment of chronic hyperuricemia. Vascular Health And Risk Management, 13:23-28. doi: 10.2147/vhrm.s115080.

31. Koeth R., Lam-Galvez B., Kirsop J. et al. (2018) I-Carnitine in omnivorous diets induces an atherogenic gut microbial pathway in humans. J. Clin. Invest., 129(1):373-387. doi: 10.1172/ ji $i 94601$.

32. Koeth R., Wang Z., Levison B. et al. (2013) Intestinal microbiota metabolism of I-carnitine, a nutrient in red meat, promotes atherosclerosis. Nature Med., 19(5): 576-585. doi: 10.1038/ nm.3145.

33. Ding L., Chang M., Guo Y. et al. (2018) Trimethylamine-N-oxide (TMA0)-induced atherosclerosis is associated with bile acid metabolism. Lipids In Health And Disease, 17(1). doi: 10.1186/ s12944-018-0939-6.

34. Verhaar B., Prodan A., Nieuwdorp M., Muller M. (2020) Gut Microbiota in Hypertension and Atherosclerosis: A Review. Nutrients, 12(10): 2982. doi: 10.3390/nu12102982.

35. Zhu Y., Li, Q., Jiang H. (2020) Gut microbiota in atherosclerosis: focus on trimethylamine Noxide. APMIS, 128(5): 353-366. doi: 10.1111/apm. 13038.

36. Hasegawa S., Ichiyama T., Sonaka I. et al. (2012) Cysteine, histidine and glycine exhibit antiinflammatory effects in human coronary arterial endothelial cells. Clin. Experiment. Immunol., 167(2): 269-274. doi: 10.1111/j.1365-2249.2011.04519.x.

37. Tanimoto A., Sasaguri Y., Ohtsu H. (2006) Histamine Network in Atherosclerosis. Trends In Cardiovasc. Med., 16(8): 280-284. doi: 10.1016/j.tcm.2006.06.001.

38. Halder M., Petsophonsakul P., Akbulut A. et al. (2019) Vitamin K: Double Bonds beyond Coagulation Insights into Differences between Vitamin K1 and $\mathrm{K} 2$ in Health and Disease. Int. J. Mol. Sci., 20(4): 896. doi: 10.3390/jims20040896.

39. Lang U., Beglinger C., Schweinfurth N. et ak. (2015) Nutritional Aspects of Depression. Cellular Physiol. Biochem., 37(3): 1029-1043. doi: 10.1159/000430229.

40. Maresz K. (2015) Proper Calcium Use: Vitamin K as a Promoter of Bone and Cardiovascular Health. Integr. Med. (Encinitas), 14(1): 34-39.

41. Riccio P., Rossano R. (2017) Diet, Gut Microbiota, and Vitamins D+A in Multiple Sclerosis. Neurotherapeutics, 15(1): 75-91. doi: 10.1007/s13311-017-0581-4.

42. Schwalfenberg G., Genuis S. (2017) The Importance of Magnesium in Clinical Healthcare. Scientifica, 2017: 1-14. doi: 10.1155/2017/4179326. 
43. Soliman G. (2019) Dietary Fiber, Atherosclerosis, and Cardiovascular Disease. Nutrients, 11(5): 1155. doi: 10.3390/nu11051155.

44. Hijová E., Bertková l., Štofilová J. (2019) Dietary fibre as prebiotics in nutrition. Centr. Eur. J. Public Health, 27(3): 251-255. doi: 10.21101/cejph.a5313.

45. Dawson M. (2000) The Importance of Vitamin A in Nutrition. Curr. Pharm. Design, 6(3): 311-325. doi: 10.2174/1381612003401190.

46. Kadri A., Sjahrir H., Sembiring R., Ichwan M. (2020) Combination of vitamin A and D supplementation for ischemic stroke: effects on interleukin-1ß and clinical outcome. Med. Glas . (Zenica), 17(2): 425-432. doi: 10.17392/1137-20.

47. Ravn H., Korsholm T., Falk E. (2001) Oral magnesium supplementation induces favorable antiatherogenic changes in ApoE-deficient mice. Arterioscler. Thromb. Vasc. Biol., 21: e858-e862.

48. RosanoffA., Seelig M. (2004) Comparison of Mechanism and Functional Effects of Magnesium and Statin Pharmaceuticals.J.Am. Coll.Nutr., 23(5):501S-505S. doi: 10.1080/07315724.2004.10719389.

49. Maier J. (2011) Endothelial cells and magnesium: implications in atherosclerosis. Clin. Sci., 122(9): 397-407. doi: 10.1042/cs20110506.

50. Fanni D., Gerosa C., Nurchi V. et al. (2021) Trace elements and the carotid plaque: the GOOD (Mg, Zn, Se), the UGLY (Fe, Cu), and the BAD (P, Ca)? Eur. Rev. Med. Pharmacol. Sci., 25(10): 3772-3790. doi: 10.26355/eurrev_202105_25945.

51. Schutten J., Joris P., Mensink R. etal. (2019) Effects of magnesium citrate, magnesium oxide and magnesium sulfate supplementation on arterial stiffness in healthy overweight individuals: a study protocol for a randomized controlled trial. Trials, 20(1). doi: 10.1186/s13063-019-3414-4.

52. Jenkins D., Spence J., Giovannucci E. et al. (2018) Supplemental Vitamins and Minerals for CVD Prevention and Treatment. J. Am. Coll. Cardiol., 71(22): 2570-2584. doi: 10.1016/j. jacc.2018.04.020.

53. Kodentsova V., Mendel 0., Khotimchenko S. et al. (2017) Physiological needs and effective doses of vitamin D for deficiency correction. Current state of the problem. Voprosypitaniia [Problems of Nutrition], 86(2): 47-62. (in Rus.).

54. Latic N., Erben R. (2020) Vitamin D and Cardiovascular Disease, with Emphasis on Hypertension, Atherosclerosis, and Heart Failure. Int. J. Mol. Sci., 21(18): 6483. doi: 10.3390/ ijms21186483.

55. Rodrigues I., Pinho C., Sobral Filho D. et al. (2021) The impact of visceral fat and levels of vitamin D on coronary artery calcification. Rev. Da Assoc. Méd. Bras., 67(1): 88-93. doi: 10.1590/1806-9282.67.01.20200388

56. Yaylali G., Dedeoglu 0., Topsakal S. et al. (2021) Relationships among Bone Metabolic Markers, Body Fat Composition and Carotid Intima-Media Thickness in Premenopausal Obese Women Acta Med Okayama, 75(3): 373-379. doi: 10.18926/AM0/62233.

57. Foroughinia F., Mirjalili M. (2020) Association between Serum Vitamin D Concentration Status and Matrix Metalloproteinase-9 in Patients Undergoing Elective Percutaneous Coronary Interventionlran. J. Pharm. Res., 19(4): 135-142. doi: 10.22037/ijpr.2020.112292.13670.

58. Zittermann A., Trummer C., Theiler-SchwetzV. et al. (2021) Vitamin D and Cardiovascular Disease: An Updated Narrative Review. Int. J. Mol. Sci., 22(6): 2896. doi: 10.3390/ijms22062896.

59. Izzo M., Carrizzo A., Izzo C. et al. (2021) Vitamin D: Not Just Bone Metabolism but a Key Player in Cardiovascular Diseases. Life, 11(5): 452. doi: 10.3390/life11050452.

60. Sokol S., Srinivas V., Crandall J. et al. (2012) The effects of vitamin D repletion on endothelial function and inflammation in patients with coronary artery disease. Vasc. Med., 17(6): 394-404. doi: $10.1177 / 1358863 \times 12466709$.

61. Witham M., Dove F., Khan F. et al. (2013) Effects of Vitamin D supplementation on markers of vascular function after myocardial infarction - A randomised controlled trial. Int. J. Cardiol., 167(3): 745-749. doi: 10.1016/j.jicard.2012.03.054.

62. Florea A., Kooi M., Mess W. et al. (2021) Effects of Combined Vitamin $K_{2}$ and Vitamin D, Supplementation on Na[18F]FPET/MRl in Patients with Carotid Artery Disease:The INTRICATE Rationale and Trial Design. Nutrients, 13(3): 994. doi: 10.3390/nu13030994.
63. Mozos I., Stoian D., Luca C. (2017) Crosstalk between Vitamins A, B , D, K, C, and EStatus and Arterial Stiffness. Disease Markers, 2017: 1-14. doi: 10.1155/2017/8784971.

64. El Asmar M., Naoum J., Arbid E. (2014) Vitamin KDependent Proteins and the Role of Vitamin K2 in the Modulation of Vascular Calcification: A Review. Oman Med. J., 29(3): 172-177. doi: 10.5001/omj.2014.44.

65. Bar A., Kus K., Manterys A. et al. (2019) Vitamin K -MK-7 improves nitric oxide-dependent endothelial function in ApoE/LDLR-/-mice. Vasc. Pharmacol., 122-123, 106581. doi: 10.1016/j. vph.2019.106581.

66. Shioi A., Morioka T., Shoji T., Emoto M. (2020) The Inhibitory Roles of Vitamin Kin Progression of Vascular Calcification. Nutrients, 12(2): 583. doi: 10.3390/nu12020583.

67. Zinöcker M., Lindseth I. (2018) The Western Diet-Microbiome-Host Interaction and Its Role in Metabolic Disease. Nutrients, 10(3): 365. doi: 10.3390/nu10030365.

68. Carracedo M., Artiach G., Arnardottir H., Bäck M. (2019) The resolution of inflammation through omega-3 fatty acids in atherosclerosis, intimal hyperplasia, and vascular calcification. Seminars In Immunopathology, 41(6): 757-766. doi: 10.1007/s00281-019-00767-y.

69. Zehr K., Walker M. (2018) Omega-3 polyunsaturated fatty acids improve endothelial function in humans at risk for atherosclerosis: A review. Prostaglandins \& Other Lipid Mediators, 134 : 131-140. doi: 10.1016/j.prostaglandins.2017.07.005.

70. Spence J. (2019) Nutrition and Risk of Stroke. Nutrients, 11(3): 647. doi: 10.3390/nu11030647.

\section{The influence of the Western diet on the development of atherosclerosis}

\section{I.O. Melnychuk, M.L. Sharayeva, V.N. Kramarova, V.G. Lizogub}

Bogomolets National Medical University, Kyiv, Ukraine

Abstract. To determine the cause-and-effect relationship between Western diet long-term adherence and atherosclerosis (AS) development. Diet is a leading lifestyle characteristic. Healthy diet violation is an important etiological factor in the most chronic diseases, including AS. AS is a chronic inflammatory disease that affects the walls of arteries and characterized by the progressive accumulation of lipids and inflammatory cells under the large arteries intima. At present, much attention is paid to the factors of cardiometabolic risk of occurrence and progression of AS as a polyetiological disease, especially in unhealthy lifestyles, including eating disorders. Today the Western diet (also called meat-sweet) is one of the leading dietary patterns in developed and some developing countries. The pathogenetic effect of such a diet is explained by its effect directly on the state of the intestinal microbiome and the imbalance of macro- and micronutrients. First, long-term adherence to the Western diet leads to the development of intestinal dysbiosis by increasing the content of gram-negative microorganisms, opportunistic pathogens. In addition, this diet is characterized by excessive consumption of saturated fatty acids, cholesterol, simple sugars, refiners, $\omega-6$ fatty acids, sodium, gluten and insufficient content of some vitamins and trace elements, namely vitamins $A, D, B_{12}$ and $K_{2}$, magnesium, chromium, polyunsaturated fatty acids, etc. It has been shown that dietary changes can reduce the risk of cardiovascular events by approximately $80 \%$. It is especially important for everyone in modern conditions to follow the principles of healthy eating to prevent AS.

Key words: Western diet, atherosclerosis, intestinal microbiome, cholesterol, saturated fatty acids.

\section{Відомості про авторів:}

Лизогуб Віктор Григорович — доктор медичних наук, професор, завідувач кафедри внутрішньої медицини № 4 Національного медичного університету імені 0.0. Богомольця, Київ, Україна. ORCID: 00000003-3603-7342

Мельничук Ірина Олегівна — кандидат медичних наук, асистент кафедри внутрішньої медицини № $4 \mathrm{Ha}-$ ціонального медичного університету імені 0.0. Богомольця, Київ, Україна. ORCID: 0000-0002-0659-1476 Крамарьова Вікторія Нилівна — доктор медичних наук, професор кафедри внутрішньої медицини № 4 Національного медичного університету імені 0.0. Богомольця, Київ, Україна. ORCID: 0000-0003-3-29783320

Шараєва Марина Леонідівна — кандидат медичних наук, доцент кафедри внутрішньої медицини № 4 Національного медичного університету імені 0.0. Богомольця, Київ, Україна. ORCID: 0000-0002-8891-7336

Адреса для кореспонденції:

Мельничук Ірина Олегівна

E-mail: ira.merkulova45@gmail.com

\section{Information about authors:}

Lizogub Victor G. - MD, Professor, Head of Internal medicine Department № 4, Bogomolets National Medical University, Kyiv, Ukraine. ORCID: 0000-0003-3603-7342 Melnychuk Iryna 0. — PhD, assistant of Internal medicine Department № 4, Bogomolets National Medical University, Kyiv, Ukraine. ORCID: 0000-0002-0659-1476 Kramarova Victoria N. - MD, professor of Internal medicine Department № 4 , Bogomolets National Medical University, Kyiv, Ukraine. ORCID: 0000-0003-3-29783320

Sharayeva Marina L. — PhD, associate professor of Internal medicine Department № 4, Bogomolets National Medical University, Kyiv, Ukraine. ORCID: 0000-00028891-7336

Address for correspondence:

Iryna Melnychuk

E-mail: ira.merkulova45@gmail.com 